\title{
Basic Party Units and Decentralised Development
}

\author{
THIAGARAJAN MANOHARAN
}

The role of the basic units of the Party (Chinese Communist Party) in decentralised development is the limited theme of this paper, published in two parts.

Development at grass root level does not arise spontaneously or fullblown; there has to be a deus ex machina. In the PRC the basic Party units plan and execute a variety of development projects; their role has to be viewed in the light of the weak administrative structure at decentralised level and the still to be completed process of separation of the Party and administration.

Studies already exist ${ }^{1}$ on the functioning of the Party and its relationship to the administration (nomenklatura system), complemented by that on the civil service system. They pertain mostly, if not wholly, to the developments at the national (and to a limited extent, at the provincial) level and mainly relate to 1984 . The departure in this paper is its analysis, centering on such aspects at the basic level, xian and downwards.

Apart from its intrinsic importance, a study of the establishment, composition and autonomy in functioning of the basic Party units, as well as the cadre system at the basic level is relevant from the perspective of decentralised development and it is attempted in this, the first part. With the supreme leadership exercised by the Party, of parallel interest is an analytical review of the self-disciplinary measures within the Party and the responsiveness of the cadres to the public's needs and views and their accountability under the still-evolving legal system. A discussion of these aspects entails a broadening of any account of the civil service system in the PRC and it will form the second part, in a forthcoming issue of Copenhagen Papers.

If information publicly available on the Party at the national level is scarce much more so it is on basic Party units. In addition to the information provided to the author, critical and analytical studies in the PRC itself have been drawn upon extensively and indicated at some tedious length in this paper. When specific information on basic Party units is not availa- 
ble, applicable information, as for instance on leading cadres, at the national level is included.

The 1987 Policy Statement ${ }^{2}$ is taken as the referral point in this paper. If the reforms at the basic level envisaged in the Statement were slow in taking effect so it will be in their reversal. The coverage of developments in the latter half of 1989 is based on what can be surmised from the excerpts published from the CCP Central Committee decision ${ }^{3}$ on further improving the economy, adopted on 9 November 1989.

\section{Separation of Party from Administration}

The reach of the state into society in the PRC is invariably equated with the reach of the Party, as can be seen in references such as State/Party, and such pervasiveness of the Party, with the incorporation of the State administrative apparatus in it. Some progress was made since the latter half of 1987 towards separation of the administrative apparatus from the Party and is reviewed below at the basic level. It had been a slow progress.

\section{Progress Made}

The separation of the administration from the commune, though officially announced in $1983,{ }^{4}$ requires separation from the government of the Party which bound together both the administration and the detailed management of the economy under the commune system.

Though the separation of the Party from the government has been much discussed and some claims made on its progress, authoritative guidelines for such separation were available only in 1987:

As the specific conditions in the central leadership, localities and enterprises differ the concrete forms of separation of functions between the Party and the government should also vary....

Under the conditions of implementing the policy of the ССP Central Committee and ensuring implementation of government decrees throughout the country in a unified way, local Party committees at the provincial, city and county levels must exercise political leadership over their local work. Their main responsibilities are to implement the directives from the CCP Central Committee and from higher Party organisations, to en- 
sure in their local areas the implementation of directives from government at higher level and from the State Council, to propose policy decisions on important local problems, to recommend outstanding cadres to local state organs and to coordinate activities of various local organisations.

The relationship between the local Party committees and government organs should be evolved through practice and gradually form a regular system.

The separation of the Party from government at xiang and zhen level is to follow that at the xian level. ${ }^{5}$ (Emphasis added)

In practice, even in the period immediately following the 1987 policy announcement, the line between the Party and the government, between policy formulation and the monitoring of its implementation, at the local level, got blurred. Unsurprising, considering the nature of the role assigned to the Party, its responsibility for major policy decisions and coordination at local level and for supervising the local implementation of State policies and decisions and its authority with respect to the appointment of the local leading cadres.

The extent and nature of the progress made following the 1987 policy statement can be gauged by the experience of ten xian from ten provinces which were held up as models by the secretariat of the CCP. ${ }^{6} \mathrm{On}$ the basis of two such xian, on which some details were provided to the author, some general observations can be made.

The separation is evolving gradually downwards from the xian level. It is being brought about by public discussions, with the Chairman of the Standing Committee of the Local People's Congress, the Chairman of the Local People's Consultative Committee and the local Party unit participating. During the separation it was agreed to by the Party that the Party supervisory committees in administrative departments will be abolished and that the local Party units will close their own supervisory departments corresponding to some administrative departments. Such abolition of overlaying units of Party control is intended to reduce Party interference in day to day administration. During the discussion of the separation process informal arrangements on the relationship between the Party and the Local People's Congress (reviewed in Part II of this paper) were also arrived at.

Some clarification of the Party providing leadership without interfering with the administration is provided by the agreement during the separa- 
tion process, as indicated by the experience in one of the two xian:

The Party is to confine itself to reviewing the annual plan, formulate the changes necessary, draw up plans for city construction, drought relief and afforestation and forward them to the administration for implementation.

On the vexed problem of allocation of fertilisers the Party is to elicit public views on the adequacy and timeliness of its supply and bring them to the notice of the administration but it is not to undertake the administrative tasks of fixing the amount or supplying to specific areas or households.

The Party will audit and review the annual budget as drawn up by the administration before it is presented to the Local People's Congress for consideration and approval.

In general, it is envisaged that the Party's views and decisions are to be conveyed to the administration through the Party unit in the Standing Committee of the Local People's Congress, thus ensuring a certain degree of popular discussion.

In the case of the other xian referred to above, the Party relinquished its direct control over the supervision of administrative departments and reduced the number of its own secretariat groups with such supervisory functions:

For instance, the Party supervision of administrative personnel was handed over in its entirety to the personnel division of the administration and the parallel units in the Party were abolished.

The Party propaganda unit will not be concerned with cultural, public hygiene and communication activities which henceforth will be fully handed over to the administration; the Party United Front secretariat will withdraw from religious and minority affairs which will be exclusively handled by the administration.

Rationalisation of the internal Party structure was carried out, reducing the number of organisations and cadres with scope for interfering with routine administration:

For instance, of the thirteen departments in the secretatariat directly under the xian Party committee only five were retained i.e. central office, Party organisation department, propaganda department, united front department and political research department.

Of the nine Party cells directly under the xian Party Committee only five were retained, those located in the Local People's Congress, Local People's Consultative Congress, People's Court, People's Procuratorate and Trade 
Union Congress; those in the administration, public security office, People's Bank and Agricultural Bank were abolished.

Of the twenty-five Party branches and units which formed the leading groups under the xian Party committee, only three were retained, namely those concerned with Party organs, civil defence and old cadres; the rest, concerned with administration and economic affairs were reduced to small groups and amalgamated.

The issue of separation of the Party from the administration in the case of collective township and village enterprises does not arise as the collective administrative organs, which are headed by the Party officials appoint the managers, formulate the budget and inspect the performance. ${ }^{7}$ Recently there has been a spurt of leasing out of small-scale enterprises on the basis of contracts. The larger proportion of them has been leased out to the local Party secretaries or high level Party officials. ${ }^{8}$

The two instances of xian cited above are among those held up as models, during the period immediately following the policy announcement in October 1987. However the umbilical cord to the Party continued to be strong. Even during 1988 and the beginning of 1989, the various public reports in the PRC indicate three differing trends: some Party units voluntarily relinquishing their control over administrative organs; the main decisions, not only at the policy but also at the administrative level, being taken by the Party units with administration carrying out such decisions; where the administration is weak or not yet fully organised, the administration completely delegating its role to the Party units (yidang dai zheng). The main effort continued to be at the xian level and even in the two xian cited here there was no perceptible indication that such comprehensive separation was reaching down to the xiang and cun levels.

Various factors account for the slow rate of change, in addition to the admitted lack of sufficient competence in the administration at the xian level and, much more so, below it and of adequate decentralisation of powers to the local government organisations. The number of secretariat units at the local Party level, forming an overlay on the administration, shows no sign of dimunition and even exceeds the norms prescribed for their number and strength by the Central Committee of the Party. ${ }^{9}$ The rectification of the Party organization, based on the four basic principles, which was begun in 1983, had proceeded from the highest level and was slow to reach the xiang and cun levels. Considering if only the numbers involved it was not an easily accomplished task. 


\section{Nomenklatura System}

A reliable indicator of the separation of the Party from administration would be a detailed information on the PRC's nomenklatura system. Such information as is publicly available pertains only to 1984 , and that too at the State (central) level, and to the devolution of the nomenklatura authority from the Central Committee of the Party to the Party's lower levels. Details on the nomenklatura system at and below the provincial level are not available. ${ }^{10}$

Two among the administrative reforms announced in 1987 and adopted, as indicated above in the two model examples of xian, have a bearing on the nomenklatura system at lower levels: ${ }^{11}$ one pertains to the overlapping of the authority of Party departments over the corresponding administrative departments; the other relates to decentralisation of powers to local Party committees.

Another indirect indication of the possible evolution of the nomenklatura system is the government personnel reform announced in 1987 for gradual implementation:

Government functionaries are to be divided into two categories: political and professional (zhengwu yuan and yewu yuan).

Political functionaries are to be handled in line with the Constitution and the Organisation Law (zuzhi fa). A system of limited tenure will be enforced. They are subject to the open supervision of society. The Party central authorities and local units at all levels and the political functionaries elected according to the recommendations by the People's Congresses under the law are to supervise and control the Party members among the political functionaries.

Professional functionaries are to be managed in accordance with the government functionary law; a system of permanent appointment will be practised. All those who intend to enter its ranks must sit for an open competitive examination. Their promotion and demotion and their rewards and punishments are to be mainly based on their performance....

Leaders and working personnel of Party organisations and leading organs will be under the management of the Party committees at all levels. A system similar to that for State functionaries will be established for organs exercising State powers, judicial organs and procuratorial organs. Mass organisations, enterprises and institutions are to work out their 
management regulations and rules. ....It will take a long time to establish and perfect such a system....12

(Emphasis added)

Some light on the nomenklatura system at the basic level is provided by a xian Party committee manual (1988) which, among others, lists the leading cadres under its direct supervision. Such cadres fall under three groups:

1. Leading officials of the departments of the xian Party committee, the leader and deputy leader of the Party committee in xiang, zhen and chengxiangzhen and representatives of xian Party committee in judicial organs.

2. Members of the Standing Committee of the xian People's Congress and director of its secretariat, members of the Standing Committee of the Local People's Consultative Congress, head and deputy-head of the xian People's Court and Procuratorate, head and deputy-head of the administration in town and township, director of civil defence.

3. Deputy directors of the departments under the Standing Committee of the People's Congress and Consultative Congress, deputy directors of departments in xian administration, deputy director of civil defence, directors of health and environment and heads of high level educational and research institutions.

In the period following the 1987 Policy Announcement the appointment of and control over the cadres in group 2 above is to be carried out by the xian Party committee in consultation with the Local People's Congress; the cadres under group 3 above are to come under the jurisdiction of the Personnel Affairs Bureau of the Administration.

\section{Basic Party Units ${ }^{13}$}

There continues to be increasing emphasis on the establishment, improvement in the membership composition and enhancement in developmental role, of the basic Party units. In practice, in their functioning the nearest and highest supervisory role is exercised by the xian Party Committee. 


\section{Organisation}

Currently, it is reported that there are 47.8 million Party members, of which 24.9 millions are in the town and townships (xiang and zhen, mainly rural areas); since 1978 to 1987 the proportion of Party members to the population in towns and townships, despite the recent emphasis in organising and supervising the basic Party units, has increased from 2.5 to 3 per cent. According to another press report, there are 2.76 million basic Party units of which 1.23 millions are in the rural areas. ${ }^{14}$

Every member of the Party belongs to a Party branch. Any Chinese citizen who has completed eighteen years of age, is willing to abide by the Party's programmes and guiding principles and by its Constitution, is willing to join a Party unit and work diligently and is ready to pay the Party membership fees regularly can apply for membership. Since 1983, in the selection of Party cadres increasing emphasis is laid on de cai jianbei (ability as well as political integrity), specifically spelt out in detail in the Party Constitution, article 35, as six basic requirements.

In brief, the Party branch (dang zhibu) is the basic Party organization (jiceng dangzuzhi). Wherever there are three or more members - as for instance in a xiang, zhen, cooperative economic group, production unit, administrative organ - a basic Party branch is established. Where the Party strength calls for it or the nature of the work requires it general Party branches (zong zhibu based on more than fifty members) are organised. Party branches are organised at the cun level and where there are less than three members a Party branch is established jointly with neighbouring cun: it is noteworthy that while the State administration reaches down only upto the xiang level; the Party reaches down further to the cun level. Where there are more than hundred Party members a basic Party committee (jiceng weiyuanhui) is formed, which supervises the branch and the general branch committees. For all practical purposes, like admission to membership and discipline, it is the Party committee which makes the decisions, not the Party branches. The committees and the branches hold periodic general meetings and elect their standing committees, according to procedures laid down in the Party constitution and Party announcements for all elections in the Party.

There have been repeated calls from the highest Party levels for the establishment and strengthening of basic Party units. ${ }^{15}$ Currently there are 69,842 towns and townships, 5,680 sub-district offices, 845,025 rural people's committees and 86,824 neighbourhood committees and the establish- 
ment and efficient functioning of basic Party units is indeed a formidable task. Two overall indicators of the progress made can be observed from the sparse statistics available. By the end of 1987, of the total Party members 27.3 percent were below 35 years of age and, compared with 1983, the members with middle and higher level education increased from 12.8 percent to 28.5 per cent. In the rural area (xiang zhen) Party members with middle and higher level education increased, as a proportion to the total, from 31.6 percent in 1983 to 39.6 percent in 1987; the corresponding decline in those with lower level education was from 51.7 percent to 46.8 percent and the proportion of illiterates, from 16.7 to 13.7 percent. ${ }^{16}$

Information on the establishment and functioning of the basic Party units in the rural areas, as on any other aspect of the internal working of the Party, is hard to come by. A survey made in 1987 of a xiang, a zhen and three cun in Shanghai city, Chuanshe xian, and of 8 representative enterprises in them, provides some indications, particularly as the xian, though prosperous, includes poor villages. ${ }^{17}$ As indicated in the table below, according to the survey, the number of Party members engaged in agricultural activities had decreased between 1983 to 1987, with a consequent increase in the number of basic Party committees in the township and village enterprises (See Table 1).

\section{Table 1. Rural Basic Party Units}

\begin{tabular}{lrrr}
\hline & 1983 & 1987 & change \\
\hline $\begin{array}{l}\text { Total number of Party } \\
\text { branches in the xian }\end{array}$ & 860 & 1121 & +261 \\
$\begin{array}{l}\text { Proportion to the total } \\
\text { of Party members in } \\
\text { primary agricultural activities }\end{array}$ & $43.4 \%$ & $34.3 \%$ & -3681 \\
$\begin{array}{l}\text { Party branches in subsidiary } \\
\text { agricultural activities }\end{array}$ & 425 & 394 & -31 \\
$\begin{array}{l}\text { Party members in manufacturing } \\
\text { as percentage of their total }\end{array}$ & $22.4 \%$ & $25.3 \%$ & +240 \\
$\begin{array}{l}\text { Total number of Party branches } \\
\text { in manufacturing units }\end{array}$ & 226 & 418 & +192 \\
\hline
\end{tabular}

The survey highlights the basic problem in the establishment and functioning of the basic Party units in the rural areas. In the villages, a significant proportion of the Party members (22.4\%) was more than 61 years old; 
nearly half the Party members had entered the Party before 1966 and are not sympathetic to the reforms and the proportion of illiterates and of those with little education accounted for $50.4 \%$. With the exodus of educated young Party members to the manufacturing sector, the Party secretary is involved in economic management, at the cost of Party construction.

For purposes of establishing and strengthening basic Party units the nearest high level Party organisation is the basic local Party congress at the xian (and corresponding administrative) level and its organ, the xian Party committee. In addition to appointing and inspecting the work of its organs the xian Congress has the power to discuss and decide important issues at the xian level in line with the principles and policies laid down by higher level Party organisations. The extent of control it exercises over the lower Party organisations varies according to the area, population, economic advancement etc. of the latter; generally the lower such organisations are the more of an implementor of the directives of the xian Party committee they are while the higher they are in the hierarchy the more latitude they are given by the xian Party committee with respect to local policy decisions. ${ }^{18}$ It is not uncommon to find xian level leading cadres devoting more attention to economic management affairs, neglecting basic Party construction work and a quota of one- fourth of their time for basic Party work is being fixed, except in the case of the xian Party secretary and deputy-secretary. ${ }^{19}$

The composition of the xian Congress reflects the responsibilities assigned to it. The number of delegates to the Congress from lower level units is fixed by the secretariat of the Party at the xian level and generally varies between 200 to 400 . Broad ratios are fixed among the various groups regarding the desirable composition of the delegates: for instance leading cadres are to form 60 per cent, skilled technicians 20 per cent, frontline leaders in various fields 18 per cent, armed forces 2 per cent, women at least 20 per cent. A proportion for minorities, based on their population, is also to be observed. Half the delegates are to be below 45 years of age. In the light of these rough overall proportions, the secretariat of the Party at lower level units draws up a preliminary list of candidates and in the finalisation of the list the Party members' views in intra-party discussions are to be fully taken into account. Beginnings were made, subsequent to the 1987 Policy Announcement, with a plurality of candidates in some xian. The voting is by secret ballot and the winning candidate needs to have at least half of the votes cast. The Party members have the right to mark on the bal- 
lot the name of any Party member other than those in the slate of candidates presented.

\section{Functioning}

The Party constitution enjoins an eight-fold task on the basic Party units; in addition to implementing Party policies and directives and promoting public awareness of them, the basic Party units are to identify and support advanced elements in socialist construction, to correct mistakes in people's views and anti-social tendencies and appropriately settle conflicts among people and to promote self-criticism among the Party members.

Since the 1987 Policy Statement there have been moves to strengthen the powers of the local Party branches (dangzuzhi de difanghua). ${ }^{20}$ So far a specific implementation to a limited extent is the relinquishing of the control exercised by the Party organisation committee at higher administrative level on the Party organisation at lower administrative level in enterprises; such control is to be vested in the local Party branches and committees. One of the important issues yet to be completely resolved is which type of enterprise,(large, medium or small) is to be put under what level of local area Party units under this change in Party leadership. Above all is the overhanging issue of the need for upgrading the professional competence of the cadres in the local Party units.

At the decentralised level the basic Party unit (in particular, the Party secretary) is exhorted to act as the leader and backbone of development activities as well as a powerful spearhead (zhandou baolei). In the context of a developing country like the PRC where the rural administrative structure is weak and the separation of the Party from the administration has not yet reached down to the basic level such a role for the basic Party units becomes meaningful. Many such model examples are held up for emulation $^{21}$ and the nature of such activities is illustrated below:

Crop planning: integrated use of land at the village level, of forestry, wasteland and cultivable land: decision on the allocation of land for household foodgrains, for individual household contracts and contracts for joint mechanised cultivation.

Rural industrialisation: at the time of separation of the commune, decisions on the allocation of commune enterprises among the collectives and private individuals; organising technical assistance from among the Party cadres. 
Mobilising financial and labour resources from the villagers for collective accumulation and investment in rural infrastructure.

Assistance to poor families: through visits and constant contacts, each Party cadre attending to the problems encountered in production and in welfare payments.

Spearheading the prevention and safety measures in times of natural disasters.

\section{Leading cadres}

Leading cadres form the backbone of the administration. The bureaucracy is in the process of being structured in keeping with the demands of modernisation; at the same time some of the forms of people's control of bureaucratic behaviour, practised since the Liberation years, have been retained. Though the central administration reaches down to the xiang level there is in practice considerable latitude for actions by the administration at the xiang level.

\section{Selection}

The selection and tenure of appointment of leading cadres ${ }^{22}$ fall into broadly four categories: by election (xuanju renqi), by internal appointment (weiren renqi), by public invitation to apply (pinren renqi) and by examination and evaluation (kaoren renqi); in internal appointment, selection made by the Party from within itself, the system of examination and evaluation has been introduced by the Central Committee in 1982. The election process, as it operates in the PRC, is applied in the case of political cadres (zhengwu yuan) and the appointment system, in the case of administrative cadres (yewu yuan). The selection of cadres from responses to public invitation to apply is, by and large, for posts requiring specialised skills. In addition to the emphasis on cadres' ability as well as political integrity (de cai jianbei) the cadre system is to be modernised fulfilling four requirements. It should have more political consciousness, have a younger age-profile, be more educated and professional (geming hua, nianging hua, zhishi hua, zhuanye hua). The four criteria are to be applied, in particular, in the case of leading cadres. 


\section{Internal selection and promotion}

Public examination system for selection of cadres is conducted by the administration at and above the xian level: entrance to the examination is voluntary, the questions are to be set in consultation with the departments concerned and the candidates are to be examined in groups. The selected candidates are to be vetted for their political awareness and, to summarise a highly involuted procedure, have to be approved by both the higher level Party committee and administrative units. The job titles and grades have been announced, with a view to enforcing a job responsibility system; however it is a common refrain of commentators in China that it is not scientific. The Party committee is enjoined to elicit the assessment of the cadres by the public. The dossier on the candidates is also consulted. ${ }^{23}$ Among the ten features of the cadre to be listed in the dossier are the cadre's political consciousness and class origin; according to the Party regulation of 1980, as revised in 1983, the inclusion of the class origin of the cadre is to get a complete profile and is not meant for purposes of selection and promotion.

Evaluation of the cadres is organised by the Party unit at next higher level, in cooperation with the administrative organs. The evaluation also takes place within the Party. The cadres are asked to evaluate the performance of their superiors in three broad groups - outstanding, competent and not competent. Such evaluation takes place and is transmitted in confidence to the next higher level Party unit which organises it. Usually such evaluation takes place departmentally; though the public is supposed to participate, at best such participation is confined to non-Party members in the same department. The absence of a scientific job classification, the lack of inter-departmental comparison and the broad classification of competence into three groups and other obvious aspects renders this process of limited validity. There are frequent reports in the press on the results of such evaluation, with comparatively less references to promotion or demotion of cadres as a consequence. ${ }^{24}$

More scientific methods of evaluation are now being introduced on a trial basis. ${ }^{25}$ The factors to be judged are political consciousness (de), ability (neng), diligence ( $q$ in) and physical condition ( $t i)$.

In the absence, again, of overall Party statistics, some accounts appearing in Chinese journals have to be drawn upon for a study of the present attributes of the leading cadres. ${ }^{26}$

According to the published accounts, cadres are still promoted and 
selected from internal ranks. In the case of cadres selected during and before the Cultural Revolution, internal promotion (taijie shi) and the stress on class origin (weicheng fenlun) were the dominant factors. Their continuing impact can be gauged by one of the findings in a country-wide survey in September 1986 of the leading Party cadres in 177 xian including cities and $q i$ (county-level administration in national minority areas): out of 1,760 seniormost Party officials, 708 had entered the Party during or before the Cultural Revolution. According to the same survey, of the 1,826 leading cadres whose age was surveyed, $60 \%$ was below 45 years of age and $8 \%$ below 35 while those above 56 accounted for $14 \%$.

On the extent of education and specialisation of the leading cadres the province-wise findings of a survey of 685 leading cadres in Hubei province are summarised below: (See Table 2 and Table 3 ).

Table 2.Cadre Specialisation ( \%)

\begin{tabular}{lccccc}
\hline $\begin{array}{l}\text { Enginee- } \\
\text { ring }\end{array}$ & $\begin{array}{c}\text { Finance } \\
\text { Econo- } \\
\text { mics }\end{array}$ & $\begin{array}{c}\text { Culture } \\
\text { History } \\
\text { Philosophy }\end{array}$ & $\begin{array}{c}\text { Economic } \\
\text { Manage- } \\
\text { ment }\end{array}$ & $\begin{array}{c}\text { Politics } \\
\text { Law }\end{array}$ & Others \\
\hline 45.4 & 7.88 & 26.08 & 2.18 & 3.56 & 16.14 \\
\hline
\end{tabular}

Table 3. Cadre Training Requirements (\%)

\begin{tabular}{lccc}
\hline Stage of study/subject & Systematic & In part & Not at all \\
\hline $\begin{array}{l}\text { Understanding of 'four } \\
\text { basic principles' }\end{array}$ & 38.33 & 53.72 & 7.45 \\
$\begin{array}{l}\text { Scientific leadership } \\
\text { and management }\end{array}$ & 7.30 & 67.30 & 25.40 \\
\hline
\end{tabular}

The study identifies the areas where the knowledge of the leading cadres has to be supplemented and lists their number as proportion to the total surveyed: modern management, $62.63 \%$; scientific leadership (lingdao kexue), $60.4 \%$; economic management, $45.55 \%$; and basic understanding of Marxism, $32.7 \%$. Of urgent importance, according to the survey, is the need for strengthening of the leading cadres' skill in understanding and implementing policies (juece nengli) among $34.89 \%$ of them, in their communication skills, $33.87 \%$ and in their specialised skills (zhuanye nengli), $31.01 \%$. 


\section{Democratic Election of Leading Cadres}

Under the 1986 law $^{27}$ the commanding positions in the local administration and in judicial organs are filled by elections by Local People's Congress at xian and corresponding administrative levels: the head and deputy head of the local administration and, subject to the concurrence at their higher levels, the head of the People's Court and the People's Procuratorate. The Local People's Congress at xiang and similar administrative levels elect only the head and deputy head of the local administration; the appointments to judicial organs come from their higher levels. The law also provides that any inappropriate (bu shidang) decision by a lower level Local People's Congress can be set aside by the next higher level People's Congress.

In its working, so far, the electoral process for the selection of political officials has resulted in all these appointments going to the Party members. At the xian level, it is the Standing Committee of the People's Congress ( there being no Standing Committee at the xiang level) which in close consultation with the Party Committee in the Congress proposes candidates and, except in the case of deputy chief of the administration, the proposals equal the number of posts. The majority in the Standing Committee (as well as in the Congress) consists of Party members though other groups are represented; in fact, to avoid conflict between the Congress and the Party there are some instances where the Chairman of the Standing Committee is also the local Party Secretary.

Under the 1987 law, ${ }^{28}$ self-government by the villages (cun) is vested in the Village People's Committee elected by all the villagers above 18 years of age or representatives from each household. The chairmen of the Village People's Committee, and its sub-committees, mainly the People's Mediation Committee, the Public Security Committee and the Public Health Committee, are directly or indirectly elected by the villagers. The leading office-holders are invariably Party members.

The details regarding the establishment, dissolution and internal working of the Village People's Committee are to be fixed by the State administration at the xiang level. All arrangements and decisions have to be reported to the State administration at the xian level. All these administrative units at the xian and xiang levels are, as seen above, headed by:Party members, thus reflecting on the composition of the Village People's Committee. In fact, according to some local accounts, heads of the Village Committees are not infrequently appointed by higher level administration. 
Experience with the operation of the 1987 law is still limited and the Village People's Committees still function as the former production brigades did, particularly in villages where village collective enterprises are important and contribute to the general development of the villages. Considering that in the villages the Party members are generally better educated it is hardly surprising that the leading positions go to them.

\section{Selection by Public Notification}

Posts requiring specialised skills in the technological and economic management fields are to be filled by public notification inviting applicants. ${ }^{29}$ The positions have to be in the national job allocation plan. The implementation of the system is under the guidance of the personnel bureau at the provincial level. Along with the professional qualifications the requirement of political consciousness (de) is to be kept in mind.

Many factors, according to the commentators in PRC, ${ }^{30}$ inhibit a fuller application of this system: the progress still to be made in scientific job classification and job description; the limits placed on mobility, particularly on skilled and scientific personnel; the frequent failure to conduct examination in groups, as required by law and the practice of individual examination, etc. Some recent measures have expanded the scope of this system as for instance the measure introduced under the 1986 law on State enterprises, enabling employment under the contract system, and technology contract system in the rural areas.

\section{Deployment}

Job allocation to cadres is subject to overall plan. The Ministry of Personnel is nominally in charge of drawing up and executing the cadre allocation plan. Under the anouncements $\mathrm{s}^{31}$ made on 1 August 1988 cadre disciplinary actions, which are within the jurisdiction of the Party disciplinary groups in government agencies, are henceforth to be handled by the Ministry of Supervision (re-established in 1987); also, while the Party will continue to manage its own leading personnel and organs, the Ministry of Personnel will manage state administrative and judicial personnel. With the slow progress in the separation of the Party from the administration, currently both Party units and personnel departments in the administration execute the cadre deployment and related.management functions. 
Except in the case of political officials and specialists recruited by public invitation to apply, the mobility of cadres, territorially or hierarchically, is of limited extent. In practice (1989), invariably, leading cadres working in administrative and other organs at the centre and in provincial capitals, big cities and capitals of autonomous areas are moved throughout the country; leading cadres who are assigned to local areas are transferred only within their cities, autonomous regions and provinces. Cadres with a national minority background are transferred within areas where minorities live. The normal tenure at a particular place is as long as five to ten years.

In addition to the overall allocation plan, the lack of mobility is attributable, according to commentators in the PRC, to the slow progress towards scientific job classification and description, the lack of adequate information channels on vacancies, the 'locking up' of personnel departmentally, the continued preference for internal promotion, etc. The insufficiency in the rotation of cadres denies them career development and opportunities for self-improvement through on-the-job training. It also results in the establishment of personal connections (guanxi) locally.

\section{At Decentralised Level}

The basic level of administration is at the xiang level. ${ }^{32}$ After the separation of the administration from the commune, in place of $52,346 \mathrm{com}-$ munes, 91,590 xiang-zhen administrative units have been established and 698,613 production brigades have been transformed into 948,600 Village People's Committees. In the process of establishing the administrative units and the Committees, the large-sized communes were split into more than one administrative unit and large-sized production brigades were made into administrative units, with the objective of bringing people closer to the administration.

At the xiang level, apart from the heads of the administration who are appointed by the Local People's Congress the administrative cadres comprise those who are sent down from the xian administration and those whom the xiang administration directly appoints. Under the direction of the xian administration the xiang administration has started introducing the practice of public examination and selection by public invitation.

Cadre allocation below the provincial level is decided at the provincial level and invariably the administrative cadres to be sent to the rural areas, xiang and cun, are determined at the xian level. Currently, at the xiang level 
there are more than 20 branches of the xian administration. The familiar phenomenon in local administration, the responsibility of officials vertically to their higher organs and horizontally to the local superiors (and in the case of the PRC, to local Party units) has drawn critical comments at local level; added to them are the complaints that the officials sent from xian level are too many and often lack awareness of local conditions. Referred to as tiao tiao kuai kuai, the result is a lack of administrative co-ordination and accountability and local space for manoeuverability.

An important impact of the split in responsibility can be observed in the working of the central-local relations. In the PRC, though it is the centre which alone can enact fiscal tax laws, all tax collection is exclusively carried out by local officials. Also in the implementation of tax laws the provincial government is allowed to adapt them to local conditions at their discretion, a provision which local officials avail themselves of, giving tax exemptions to stimulate local development at the expense of central revenues.

In the context of local administration, an interesting experiment, held up as a model, is reported ${ }^{33}$ from Guilin province, Huaxun xian, where administrative responsibility over its cadres has been handed down to a township, Hongshi Lazi zhen. Under an agreement with the xian administration covering personnel, property and materials, the township administration will not change the job classification, status, salary and welfare benefits of the officials, nor the state-planned allocation of finance and materials. Subject to the formal approval of the xian administration the township administration will have the power to dismiss the officials, if necessary; such powers over Party cadres in the administration will be exercised by the Party branch at the township level. In any transfer, promotion or removal from office of the officials at the townshiplevel, the xian administration has to seek the concurrence of the township administration.

\section{Exit}

The retirement age of the administrative cadres has been fixed at 60 years for males and 55 for females, with a minimum of fifteen years of service. In the Party, for cadres holding senior positions at the centre and in provinces, cities and autonomous regions the retirement age is 65. Subject to the approval of higher authorities the cadres can leave the administration or the Party.

To encourage a younger age-composition and the exit of cadres of the 
Cultural Revolution vintage, there has been a series of regulations. ${ }^{34}$ The financial support for those who leave are generally more generous than that for those who retire normally; it is based on the length of revolutionary service (canjia geming gongzuo shijian), which has been precisely defined. ${ }^{35}$

The Party has repeatedly called for the exit of cadres who, because of old age or health conditions, cannot function adequately. As an indirect inducement for elderly administrative officials, particularly the scientific and technical cadres, to exit, they are allowed to engage in economic activities and are subsidised if their earnings fall short of minimum requirements; but they are cautioned against misusing their old official connections.

The impact of such encouraging policies has not been significant, as can be seen from the statistics on the age-composition of Party members given above.

\section{Personnel Statistics}

Some approximate estimates of the total strength of leading cadres are given below (Table 4):

Table 4. Cadre Strength (1985, in million)

\begin{tabular}{lcc}
\hline & $\begin{array}{c}\text { Staff and } \\
\text { workers }^{1}\end{array}$ & $\begin{array}{c}\text { Leading } \\
\text { cadres }^{2}\end{array}$ \\
\hline $\begin{array}{l}\text { State (total) } \\
\text { At xian level } \\
\text { and below }\end{array}$ & 5.97 & 1.4 \\
$\begin{array}{l}\text { Collective sector } \\
\text { Cities (cheng-zhen) }\end{array}$ & 1.43 & 0.4 \\
Rural (nongcun) & 0.26 & 0.07 \\
\hline
\end{tabular}

${ }^{1 .}$ Covers national administrative organs (guojia jiguan), Party administratie organs (zhengdang jiguan) and social groups (shehui tuanti).

${ }^{2}$ A cutt-off point of 120 yuan basic wage is applied, based on the basic salary of cadres at supervisory level in the State sector. Distribution of staff by salary groups is given by a sample survey of 2,049 State units; for the collective sector, the porportion given for agriculture and related units is applied.

Sources: Zhongguo Tongjiju, Shehui Tongjisi bian, Zhongguo Laodong Gongzi Tongji Ziliao 1949-1985 (Beijing: Zhongguo Tongji Chubanshe, 1987) (PRC wage statistics publication). 
The administrative establishment, whose strength is tentatively estimated above is impressive. Its self-discipline and its accountability to the public form the theme of the second part of this paper.

Thiagarajan Manoharan is a Senior Research Associate at the Center for East and Southeast Asian Studies, University of Copenhagen.

\section{NOTES}

1 For instance see John P. Burns, ed., The Chinese Communist Party's Nomenklatura System (New York: M.E. Sharpe, 1989); John P. Burns, "Chinese Civil Service Reform: The 13th Party Congress Proposals, "The China Quarterly, No. 120 (December 1989), pp. 739-770; John P. Burns, "China's Nomenklatura System, « Problems of Communism, (September-October 1987), pp. 36-51; John P. Burns, "Civil Service Reform in PostMao China, "Chapter 4 in Joseph Y.S. Cheng, ed., China: Modernization in the 1980s (The Chinese University of Hongkong, 1987); Melanie Manion, "The Cadre Management System, PostMao: The Appointment, Promotion, Transfer and Removal of Party and State Leaders," The China Quarterly, No. 102 (June 1985), pp. 203-233; Melanie Manion, ed., Cadre Recruitment and Management in the PRC, Chinese Law and Government, Vol XVII, No. 3(Fall 1984), (New York: M.E. Sharpe, 1984).

2 Zhao Ziyang, "Yanzhe you Zhongguo tese de shehuizhuyi daolu qianjin“ (Advance along the road of socialism with Chinese characteristics), Renmin Ribao, November 4, 1987.

3 Zhonggong Zhongyang, "Guanyu jinyibu zhili zhengdun he shenhua gaige de jueding (zhaiyao)" (The CCP Central Committee's decision on further improving the economic environment rectifying the economic order and deepening the reform (excerpts)),
Renmin Ribao, January 17, 1990, pp. 1-3, Hereafter 1989 Zhengdun.

4 As announced in Zhonggong Zhongyang, Guowuyuan guanyu shixing zhengshe fenkai jianli xiangzhengfu de tongzhi (CCP Central Committee, State Council notification concerning the separation of the administration from the commune and the establishment of township administration), October 12, 1983.

5 Zhao Ziyang, "Yanzhe you Zhongguo tese de shehuizhuyi daolu qianjin."

6 See the short press summaries: "Yaoqiu jiaqiang nongcun jiceng dang zuzhi jianshe" (A call for establishing strengthened rural basic Party units), Renmin Ribao, August 16, 1987, p. 4; "Ba xian jiaqiang xianji lingdao banzi jianshi" (Ba county strengthens the establishment of county-level leading group), Renmin Ribao, February 14, 1987, p. 4. The account in the main text is based on details regarding two of those ten xian, as furnished to the author during his field study. The identification of the two xian is withheld by the author.

7 The role of the Party committee in State enterprises has been specifically laid down in official regulations and city enterprises, specifically the large ones, are increasingly adopting the practices in State enterprises. An analysis of such practices falls outside the purview of this note. The appointment process regarding enterprise managers which 
was surveyed in 900 enterprises, with close to one-fifth of them collective enterprises, in 1985 indicate the preponderance of bureaucratic appointees: $60.1 \%$, bureaucratic appointment; $30.7 \%$, bureaucratic appointment in consultation with workers; $4.4 \%$, directly elected by the factory employees; $1.0 \%$, through Workers' Congress; and $1.8 \%$, through management contracts.

For details see Zhongguo Jingji Tizhi Gaige Yanjiusuo, Gaige: women mianlin de tiaozhan yu xuanze (Reform: challenges and choices facing us) (Beijing: Zhongguo Jingji Chubanshe, 1986), p. 273. The statement on CTVEs and leased-out enterprises is based on the author's field study.

8 See, for instance, Hu Zuyan, "Zuren qiye dangzhibu ruhe fahui baozheng jiandu zuoyong " (How to bring into full play and ensure the supervision by party units in leased enterprises) Xuexi Dabao, 1988, No. 4, p. 29. In Changde prefecture, of the 45 enterprises leased out, 19 were to the local Party secretaries, 20 to senior Party members and only 6 to private individuals. In fact, as the leased-out units are economically and managerially weak, there is a growing perception that Party cells should be formed in them to provide guidance. See, for instance, Heilongjiang Shengwei Zuzhibu Zuzhichu, "Guanyu zurenqiye dang de jianshe gongzuo qingkuang de diaocha« (An investigation of the situation regarding the work of establishing the Party in leased enterprises), Dang Jian, 1988, No. 4 , pp. 40-41.

9 For details see Xiao Li, »Anzhao dang zheng fenkai de yuanze tantao gaige dang de gongzuo jigou de luzi« (A discussion of the approaches to reform of work organization of the Party according to the principle of the separation of the Party from administration), Zheng- zhixue Yanjiu, 1988, No. 2, pp. 7-10. Also Niu Yaying, Li Jun, "Lishun dang zheng jigou shi shixian zhizheng dang de lingdao zhineng de genben tujing " (Smoothening the Party - administration structure is the basic route for realising the leadership functions of the party in power), Dangzheng Luntan, 1988, No. 3, pp. 18-23.

10 Information on the PRC's nomenklatura system is restricted. Some information, as of 1984, is available in an internal publication: Zhongguo Renmin Yinhang Renshisi, Renshi gongzuo wenjian xuanbian (Selected documents on personnel work) (Zhongguo Jinrong Chubanshe, 1985). Hereafter RSGZ. In a reform announced in 1983, the number of cadres under the direct management of the Central Committee of the Party was reduced from 13,000 to 7,000 and the nomenklatura authority was transferred to Party committees and other cadre management units at lower levels. The objective of such decentralisation was to promote efficient personnel management. See "Yi gaige de jingshen jiasu lingdao banzi he ganbu duiwu de "sihua "jianshe" (For establishing vigorous and speedy 'four modernisations ${ }^{\prime}$ of leading groups and cadre ranks). RSGZ, p. 114.

111987 Policy Statement:

On overlapping of authority: Party departments that overlay corresponding government departments should be abolished; the administrative affairs they are now handling should be handed over to government departments. Party leading groups in government departments, which are responsible to the Party committees at the next higher level, should be abolished gradually. Discipline inspection commissions of the Party should not deal with infractions of law or of administrative regulations but should concentrate on fostering Party spirit and enforcing 
Party discipline.

On decentralisation of powers: Party organisations in enterprises and institutions - which are now under the direct leadership of Party organisations at the next higher level - should gradually be transferred under the leadership of the local Party committee.

12 Zhao Ziyang, "Yanzhe you Zhongguo tese de shehuizhuyi daolu qianjin."

13 The basic source for this and other sections is naturally the Party Constitution as approved by the 12th National Party Congress, September 6, 1982 and amended by the 13th National Party Congress, November 1, 1987). See also, Guanyu dangnei zhengzhi shenghuo de ruogan zhunze (Zhongguo Gongchandang Di Shiyi Jie Zhongyang Weiyuanhui Di Wu Ci Quanti Huiyi tongguo) (Some norms for political activities within the Party as approved by the 5 th plenary session of the Central Committee at the 11th Party Congress). For specifically on Party branch (the manual which the author found to be in regular use, during his field study) see Dang zhibu gongzuo shouce (Handbook on Party branch work) (Shanghai: Renmin Chubanshe, 1985). Also see, for instance: Wang Jianxin, Yang Shuhai, Qian Shuhai, Qian Guoliang and Yan Dianru, Ganbu guanli gailun (Introduction to cadre management) (Shenyang: Liaoning Daxue Chubanshe, 1986); Zhongyang Heilongjiang Shengwei, Dangde shenghuo zhishi shouce (Handbook of instructions on Party activities) (Beijing: Zhongguo Zhanwang Chubanshe, 1986); Zhonggong Zhongyang Zuzhibu Yanjiushi, Zuohao xin shiqi de ganbu gongzuo (Doing well the cadre work in the new period) (Beijing: Renimin Chubanshe, 1984); Song Qiong, Tian Jimin, Dangyuan shouce (Handbook for Party members) (Beijing: Huaxia Chubanshe, 1987); Zhang
Wanli, ed., Dang de jianshe (Party construction) (Beijing: Zhongguo Renmin Daxue Chubanshe, 1988). Where analytical statements and conclusions are not in the references specifically cited, they are based on the author's field study. The identity of places, persons and institutions is withheld by the author.

14 "Quanguo nongcun dangyuan da er qian si baiduo wan" (In the whole country rural party members exceed 24 million), Nongmin Ribao, July 1, 1988, p. 1. "Zhonggong jiu nian fazhan yi qian er baiduo wan xin dangyuan « (In nine years CCP admits 1.2 million new party members), Renmin Ribao, June 23, 1988, p. 1. The Party does not release to the public statistics and internal work reports.

15 See, for instance, "Zhongshi jiceng dangzheng jianshe" (Establish Chinese-style basic party-administration), Renmin Ribao, February 25, 1988, p. 1.

16 Op. cit., note 14.

17 See Shanghaishi Dangjiao Xitong Dang de Jianshe Diaochazu, „Guanyu Shanghaishi Chuanshe xian nongcun jiceng dang zuzhi jianshe zhuangkuang de diaocha" (Investigation of conditions regarding rural basic party units in Chuanshe County, Shanghai City), Dangzheng Luntan, 1988, No. 11, pp. 38-42.

18 See Hu Guozhang, Zhang Deshun and Fan Huyang, "Shilun difang dangwei de wu da tezheng" (Views on five important characteristics of local Party committees), Xuexi Yu Shijian, 1988, No. 10, pp. 43-45.

19 See Shengwei Zuzhibu Nongcun Zuzhichu, "Jiaqiang nongcun dang de jianshe de jiben jingyan - dui lishideng ba ge xian (shi) quwei de diaocha" (Strengthen basic experience in rural Party construction - an investigation of Party committees in eight counties (ci- 
ties) and prefectures, at managerial level), Xin Changzheng, 1988, No. 12, pp. 28-30.

20 See, for instance, Liu Mingmo, „Dui qishiye danwei dang zuzhi shudi guanli de sikao" (Reflexion on Party units managing the dependency of enterprise management units), Dangzheng Luntan, 1988, No. 5, pp. 33-37; Liu Yifeng, "Shi lun jiceng dang zuzhi 'difanghua' wenti« (Tentatively on the question of 'localization' of basic Party organizations), Chengdu Shiwei Dangjiao Xuebao, 1988, No. 1, pp. 11-12; Li Jifeng, "Shilun difang dangwei dui difangxing zhongda wenti de juece (Reflexions on local Party committees deciding on important local issues), Renshi, 1988, No. 3, pp. 6-8.

21 For specific details see the many model examples given in Zhonggong Zhong yang Zuzhibu Zuzhiju, Zai gaige he jianshe zhong zengqiang jiceng dang zuzhi de huoli - quanguo jiceng dang zuzhibu gongzuo jingyan xuanbian (In the reform and construction process enhance the vitality of basic Party units - collection of selected experience country-wide of the working of basic Party units) (Beijing: Zhonggong Dangshi Ziliao Chubanshe, 1987).

22 The term lingdao ganbu is generic with respect to all functionaries at some not precisely defined level of responsibility, be they members of the Party or not; in this note, unavoidably, no distinction is made between the two and the analysis applies to both.

23 The national law on the dossier system was approved by the 22nd session of the Standing Committee of the National People's Congress, September 5, 1987. For the earlier regulation see Guojia Danganju, Danganguan gongzuo tongze (National Dossier Office, General rule on dossier offices), April 26,1983 . The basic dossier office is at the county level, numbering 2,100, 85 percent of the national total. For details of the contents, with specimen forms, arrangements for storage and confidentiality, availability and use see Chen Zhiwei, Li Guoqing, Xian danganguan yewu zhishi (Instructions for county dossier office functions) (Guizhou: Renmin Chubanshe, 1987).

24 See, for instance, the report on Fujian, Guangdong and Gansu provinces, at city and xian levels in "Geti minzhu kaoping lingdao ganbu qude chengong « (Successful democratic examination of leading cadres individually), Renmin Ribao, July 11, 1987, p. 4; "Xianji ganbu niandu gongzuo kaoke jiang kuoda shidian" ( Expansion of pilot project on annual examination of the work of cadres at county level) Renmin Ribao, September 25, 1987, p. 4; for a report on demotion of cadres as a result of evaluation see $»$ ianshibu minzhu kaoping sijiu ji ganbu « (Democratic examination of cadres in 49 grades by Construction Ministry) Renmin Ribao, October 15, 1987, p. 1. For a perception in China of the limitations of the evaluation system, see, for instance, Zhang Hua, "Shilun dui xianji dangzheng lingdaoganbu shixing quanmian kaoke" (Views on the all-round examination of leading cadres in Party and government at the county level), Kexue Shehuizhuyi Yanjiu, 1988, No. 4, pp. 4345.

25 See, for instance, Zhu Zongwei, »Ben shijuji dangzhongganbu ceping xiaoyi« (Surveying the effectiveness of cadres in Central Committee Offices at city level), Shehui Kexue, 1987, No. 8., pp. 54-55, 16. Also, Laodong Renshibu Xingzhengguanli Kexue Yanjiusuo Zuzhi bianxia, Guojia gongwuyuan zhidu jianghua (National civil service system explained) (Beijing: Laodong Renshi Chunbanshe, 1988).

26 See, for instance, Wu Yue, "Difang dangzheng lingdao ganbu xuanba yu 
jiandu zhuandong moshi de libi zhiyao" (Advantages and disadvantages in the revolving pattern of choice and supervision of local leading cadres in Party and government), Zhengzhixue Yanjiu Ziliao, 1988, No. 2, pp. 24-28; E Zupei, "Dangqian lingdao ganbu dui peishun de xuqiu“ (Currently arranging leading cadres in orderly sequence), Hubei Dangitao Xuebao, 1987, No. 3, pp 30-32; Wang Ziji, "Xin xingshixia de xin keti (New task under new form), Changbai Xuekan, 1987, No. 4, pp. 49-52.

27 The latest Law on Local People's Congress and Local Administration was approved by the National People's Congress on December : 2 1986. The observations in this paper are based on another field survey, on the working of the Local People's Congress and of Village People's Committee, in 3 counties, 3 cities, 2 districts, 6 townships and 4 villages. For a detailed discussion see Thiagarajan Manoharan, »The working of the 1986 Local People's Congress Law (forthcoming).

28 The PRC law on establishment of village People's Committee went into effect on June 1, 1988.

29 For some illustrative job specifications see Guojia Jingwei Zhicheng Gaige Gongzuo Bangongshi, Pinren jingji zhanye zhiwu wenjian huibian (Collection of documents on contract appointments) (Beijing: Qiye Guanli Chubanshe 1987).
30 For instance see Laodong: Renshibu Xingzhengguanli Kexue Yanjiusuo Zuzhi bianxia, Guojia gongwuyuan zhidu jianghua, pp. 111-112.

31 «Zubu chexiao Guowuyuan ge bumen dangzu« (Gradually abolish party cells in every ministry under the state council), and "Zubu chexiao Guowuyuan ge jijianzu he zhong jiwei paizhu jijianzu" (Gradually abolish all party disciplinary groups and central disciplinary committee's control over the groups in the state council), Renmin Ribao, August 1, 1988, p. 1.

32 Fazhan Yanjiusuo Zonghe Keti Zu, ed., Gaige: mianlin zhidu chuangxin (Reform: facing new ideas on institutions) (Shanghai, 1988), pp. 219-233.

33 See Liu Zhenwei, Wang Zhenyao, eds., Xiangcun zuzhi tizhi gaige (System reform of township-village organization) (Beijing: Zhongguo Linye Chubanshe, 1987), pp. 119-120.

34 They include, Temporary Provisions Regarding Arrangements Helping the Settling Down of Old, Ill and Disabled Cadres, June 2, 1978; Temporary Provisions Regarding Old Cadres' Leaving the Party for Rest and Recuperation, April 13, 1982; Decision on the Enhancement of Retirement Benefits and Living Allowances of Part-time Employed Senior Officials, June 28, 1983.

35 For details see Tan Jian, ed.; Guojia Gongwuyuan Shouce. (Handbook on national civil service) (Beijing: Shehui Kexue Wenxian Chubanshe, 1988), Chapter 13, pp. 238-250. 